\title{
Activation of ErbB2 during Wallerian Degeneration of Sciatic Nerve
}

\author{
Yunhee Kim Kwon, ${ }^{1,2,5}$ Anita Bhattacharyya,, ${ }^{2,5}$ John A. Alberta, ${ }^{2}$ William V. Giannobile, ${ }^{2,4}$ Kangwoo Cheon, ${ }^{1}$ \\ Charles D. Stiles, ${ }^{2}$ and Scott L. Pomeroy, ${ }^{3}$ \\ ${ }^{1}$ Department of Biology, College of Arts and Sciences, KyungHee University, Seoul, 130-701 Korea, ${ }^{2}$ Department of \\ Microbiology and Molecular Genetics, Harvard Medical School and the Dana-Farber Cancer Institute, Boston, \\ Massachusetts 02115, 32Department of Neurology, Harvard Medical School and Children's Hospital, Boston, \\ Massachusetts 02115, and 4 Department of Periodontology, Harvard School of Dental Medicine, \\ Boston, Massachusetts 02115
}

We used anti-phosphopeptide-immunodetecting antibodies as immunohistochemical reagents to define the location and activity state of $\mathrm{p} 185^{\text {erbB2 }}$ during Wallerian degeneration. Nerve damage induces a phosphorylation event at Y1248, a site that couples $\mathrm{p} 185^{\mathrm{erbB} 2}$ to the Ras-Raf-MAP kinase signal transduction pathway. Phosphorylation of $\mathrm{p} 185^{\mathrm{erbB} 2}$ occurs within Schwann cells and coincides in time and space with Schwann cell mitotic activity, as measured by bromodeoxyuridine uptake. These visual images of receptor autophosphorylation link activation of $\mathrm{p} 185^{\text {erbB2 }}$ to the Schwann cell proliferation that accompanies nerve regeneration.

Key words: neuregulin; erbB2; receptor tyrosine kinase; Schwann cell; Wallerian degeneration; phosphotyrosine
Unlike elements of the CNS, peripheral nerves can regenerate when damaged. Understanding the regulation of this process has practical implications for treatment of peripheral neuropathies such as those secondary to diabetes, cancer chemotherapeutic agents, and other toxins. Moreover, insights into peripheral nerve regeneration may be transferable to treatment of spinal cord injuries. After peripheral nerves are damaged, they initially undergo Wallerian degeneration. Axons distal to the site of injury degenerate, and their myelin sheaths break down. Schwann cells then proliferate, providing a context for axonal regrowth and nerve regeneration (Waller, 1851; Fawcett and Keynes, 1990). Although Schwann cell proliferation is a prominent feature of nerve regeneration, the molecular signals driving the mitotic response have not been characterized.

One viable candidate for regulating the Schwann cell proliferation that accompanies regeneration of peripheral nerves is the transmembrane tyrosine protein kinase $\mathrm{p} 185^{\mathrm{erbB} 2}$. Schwann cells express p185 ${ }^{\text {erbB2 }}$ both in culture and in vivo (Jin et al., 1993; Marchionni et al., 1993). The tyrosine kinase activity of $\mathrm{p} 185^{\mathrm{erbB} 2}$ is activated by a family of ligands known collectively as the neuregulins (glial growth factor, acetylcholine receptor-inducing activity, Neu differentiation factor, and heregulin) that are encoded as splice variant transcripts of a common gene. Neuregulins are expressed by neurons in the peripheral nervous system (Marchionni et al., 1993; Dong et al., 1995), and they promote the

Received June 19, 1997; revised Aug. 5, 1997; accepted Aug. 11, 1997.

The work was supported by National Institutes of Health Grants NS27773 and HD18655 (S.L.P.) and HD24926 (C.D.S.), and from Korean Science and Engineering Foundation Grant 95-0403-03 for cell differentiation through BIOTECH 2000, (S.R.C.), and KyungHee University (Y.K.K.). We thank Pieter Dikkes for technical assistance.

In compliance with Harvard Medical School guidelines on possible conflict of interest, we disclose that C.D.S. has consulting relationships with Upstate Biotechnology and Sandoz Pharmaceuticals Inc.

Y.K.K. and A.B. contributed equally to this work.

Correspondence should be addressed to Scott L. Pomeroy, Department of Neurology, Children's Hospital, 300 Longwood Avenue, Boston, MA 02115.

Copyright (C) 1997 Society for Neuroscience $0270-6474 / 97 / 178293-07 \$ 05.00 / 0$ proliferation of Schwann cells in vitro (Marchionni et al., 1993; Marchionni, 1995; Morrissey et al., 1995).

Activation of the $\mathrm{p} 185^{\mathrm{erbB} 2}$ tyrosine kinase results in the autophosphorylation of specific tyrosines on the intracellular domain of the receptor. This autophosphorylation can be monitored with anti-phosphotyrosine antibodies. However, reactivity with generic antibodies to phosphotyrosine provides no specific insight into the catalytic or signaling activities of a growth factor receptor. Moreover, anti-phosphotyrosine antibodies cannot be used as receptor-specific histochemical reagents. To determine the cellular location and activity state of $\mathrm{p} 185^{\mathrm{erbB} 2}$ during Wallerian degeneration, we exploited the fact that synthetic tyrosine phosphopeptides, corresponding to major autophosphorylation motifs, can be used to raise anti-phosphopeptide-immunodetecting (APHID) antibodies (Bangalore et al., 1992; Epstein et al., 1992). These APHID antibodies report the phosphorylation state of specific tyrosine residues within a targeted growth factor receptor or phosphoprotein. In the present study, we use an APHID antibody to monitor the activation state and signaling functions of p185 ${ }^{\mathrm{erbB} 2}$ in an injured sciatic nerve. We show that $\mathrm{p} 185^{\mathrm{erbB} 2}$ becomes phosphorylated in proliferating Schwann cells during Wallerian degeneration. Moreover, phosphorylation occurs at a position that couples $\mathrm{p} 185^{\mathrm{erbB} 2}$ to the Ras-Raf-MAP kinase signal transduction pathway.

\section{MATERIALS AND METHODS}

Cell culture. The G8/DHFR cell line was a generous gift from the laboratory of Robert Weinberg (Massachusetts Institute of Technology). These murine fibroblasts, which overexpress the rat c-erbB2 gene product, were cultured, and cell lysates containing either unactivated or activated p185 ${ }^{\text {erbB2}}$ were prepared as described previously (Epstein et al., 1992).

Surgical procedures. To obtain nerve samples, male Sprague Dawley rats $(\sim 250 \mathrm{gm})$ were anesthetized with sodium pentobarbital $(50 \mathrm{mg} / \mathrm{kg})$. Using aseptic technique, the right sciatic nerve was exposed $1.0 \mathrm{~cm}$ distal to the sciatic notch, doubly ligated, and transected. The rats were allowed to recover from surgery. Later, the animals were anesthetized to harvest the sciatic nerves.

Immunoprecipitation and immunoblotting. Immunoprecipitates of 


\section{Activation of ErbB2 in the distal stump.} days after transection

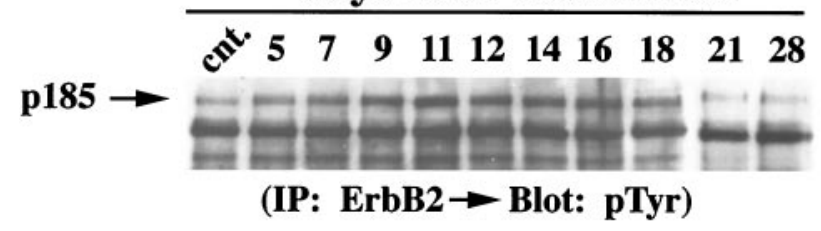

Figure 1. Tyrosine phosphorylation indicative of $\mathrm{p} 185^{\mathrm{erbB} 2}$ activation in sciatic nerve during Wallerian degeneration. $\mathrm{p} 185^{\mathrm{erbB} 2}$ immunoprecipitates were prepared from uncut sciatic nerve (cnt) or from the distal stump of nerves from 5 to $28 \mathrm{~d}$ into Wallerian degeneration as described in Materials and Methods. The immunoprecipitates were size-fractionated on $7.0 \%$ SDS-polyacrylamide gels and immunoblotted with a monoclonal antibody to phosphotyrosine. The arrow on the left indicates position of $\mathrm{p} 185^{\mathrm{erbB} 2}$.

p185 ${ }^{\text {erbB2 }}$ were prepared from uncut sciatic nerve or from the distal stump of the nerve at 5-28 d into Wallerian degeneration. To obtain samples for immunoprecipitation and immunoblotting, the proximal and distal stumps of the cut nerve and the opposite uncut nerve were excised and snap frozen in liquid nitrogen. To prepare lysates, frozen nerve samples were minced with a razor blade on top of dry ice. The samples were then homogenized with eight strokes in a Dounce homogenizer in lysis buffer (1\% NP-40, $20 \mathrm{~mm}$ Tris, pH 7.4, $150 \mathrm{~mm} \mathrm{NaCl}, 10 \%$ glycerol, $1 \mathrm{~mm}$ sodium orthovanadate, $4 \mathrm{gm} / 1 \mathrm{NaF}, 8.8 \mathrm{gm} / 1$ sodium pyrophosphate decahydrate, $1 \mathrm{mM}$ PMSF, $10 \mu \mathrm{g} / \mathrm{ml}$ aprotinin, and $20 \mu \mathrm{M}$ leupeptin) and clarified by centrifuging for $10 \mathrm{~min}$ in a microcentrifuge at $4^{\circ} \mathrm{C}$. One milligram aliquots of each sample were immunoprecipitated with an antibody to $\mathrm{p} 185^{\mathrm{erbB} 2}$ [polyclonal antibody 1 (pAb-1) rabbit polyclonal from Zymed Laboratories, Inc., South San Francisco, CA] using established protocols (Harlow and Lane, 1988). The immunoprecipitates were size-fractionated on $7.0 \%$ SDS polyacrylamide gels and immunoblotted with a monoclonal antibody to phosphotyrosine (4G10; a generous gift from Tom Roberts, Harvard Medical School).

Antibody specificity was determined by competition experiments in immunoblots of G8/DHFR cells. Competing peptides (14 mer at $100 \mathrm{nM}$ ) were preincubated with antibody at $4^{\circ} \mathrm{C}$ for $2 \mathrm{hr}$ before immunoblotting. The negative and positive specificity controls were, respectively, the peptide and phosphopeptide counterparts of the sequence used to raise the p185 ${ }^{\text {erbB2 }}$ APHID antibody (tyrosine 1248 in the sequence AENPEpYLGLDVPV). Other specificity controls were tyrosine phosphopeptides containing the closely related NPXY motifs in the C-terminal domain of epidermal growth factor (EGF) receptor (phosphotyrosine 1197 in the sequence AENAEpYLRVAPQS) and the erbB4 gene product (phosphotyrosine 1284 in the sequence AEN PEpYLSEFSLK). The C-terminal portion of $\mathrm{p} 180^{\mathrm{erbB} 3}$ has no positional equivalent of the p185 ${ }^{\text {erbB2 }}$ NPXY motif.

Immunohistochemistry. For immunohistochemistry, anesthetized animals were killed by intracardiac perfusion with $4 \%$ paraformaldehyde in PBS with $1 \mathrm{~mm}$ sodium orthovanadate added to inhibit endogenous

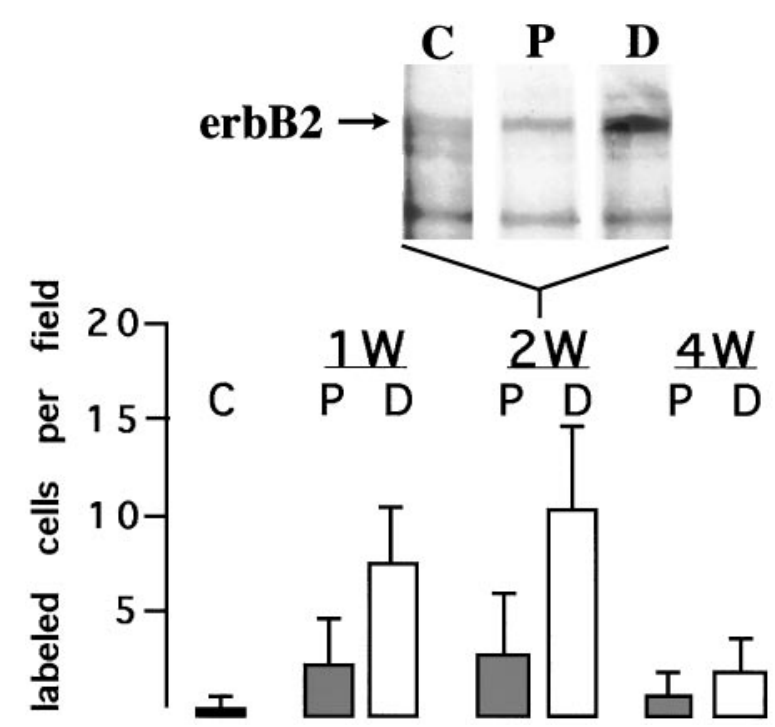

Figure 2. Schwann cell proliferation is associated with phosphorylation of $185^{\text {erbB2 }}$ on tyrosine. BrdU uptake was monitored in parallel with immunoprecipitation studies using separate animals. BrdU-labeled nuclei (mean $\pm \mathrm{SD}$ ) were counted in five high-powered fields or nerve segments ( 2 animals per time point; $W$, weeks after lesion). The highest number of labeled nuclei was found in the distal nerve stump $(D) 2$ weeks after transection, coinciding with the peak of $185^{\mathrm{erbB} 2}$ activation shown in Figure 1. Nuclear labeling increased to a lesser extent in the proximal stump $(P)$. By immunoblotting, lesser amounts of activated $\mathrm{p} 185^{\mathrm{erbB} 2}$ also were detected in the proximal stump of the lesioned nerve (inset). $C$, Control.

phosphatase activity. Cryostat sections $(7.5-10 \mu \mathrm{m})$ from proximal and distal stumps of sciatic nerve were permeabilized with $0.5 \% \mathrm{NP}-40$ in

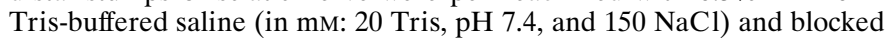
with 5\% normal goat serum. Aliquots of primary APHID antibody (100 $\mu \mathrm{l}$ ) were mixed with BSA (final concentration, $1 \mathrm{mg} / \mathrm{ml}$ ), solvent control, or competing peptide $(100 \mathrm{nM})$ as indicated in a final volume of $150 \mu \mathrm{l}$. Antibody and competing peptides were mixed with gentle rocking at $4{ }^{\circ} \mathrm{C}$ for $2 \mathrm{hr}$ before incubating with nerve sections $(150 \mu$ l over each sample on a glass slide) for $24-36$ hours at $4^{\circ} \mathrm{C}$, followed by incubation in biotinylated secondary antibody (Vector Laboratories, Burlingame, CA). Staining was visualized with True Blue (KPL, Gaithersburg, MD) or with DAB per instructions of the Vectastain ABC kit (Vector Laboratories). Identical procedures were used for immunohistochemical staining with commercial antisera to antibody $185^{\mathrm{erbB} 2}$ (Triton Biosciences, Alameda, CA) and with antisera to S100 protein (Dako, Carpinteria, CA). For double-labeling experiments, sections were permeabilized, blocked, and incubated with primary APHID antibody overnight at $4{ }^{\circ} \mathrm{C}$, followed by biotinylated goat anti-rabbit IgG (Vector Laboratories) and avidin-Cy3 (Jackson Immunochemicals, West Grove, PA). The sections
Figure 3. APHID antibody is specific for phosphotyrosine 1248 within activated p185 ${ }^{\mathrm{erbB} 2} . A, \mathrm{G} 8 /$ DHFR cells were treated with phorbol or with solvent control to generated inactive $(-)$ or activated (+) p185 ${ }^{\text {erbB2 }}$ as described in Materials and Methods. Cell lysates were size-fractionated by SDSPAGE (40 $\mu \mathrm{g} /$ lane) and immunoblotted with the APHID antibody to $185^{\text {erbB2 }}$ ( $\left.A P H I D\right)$ or with a commercial antibody that recognizes the receptor irrespective of activation state $(p A b-1) . B$, Lysates containing activated p185 ${ }^{\text {erbB2 }}$ were sizefractionated and immunoblotted with the APHID antibody to $\mathrm{p} 185^{\mathrm{erbB} 2}$ as $A$, except that the antibody was preincubated with synthetic peptides or phosphopeptides corresponding to NPXY motifs in p185 ${ }^{\text {erbB2}}$, EGF receptor, or p180 ${ }^{\text {erbB4 }}$ as described in Materials and Methods. The double-ended arrow indicates position of $200 \mathrm{kDa}$ molecular weight standard.

\section{A. antibody B. competing peptide}

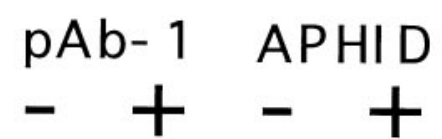

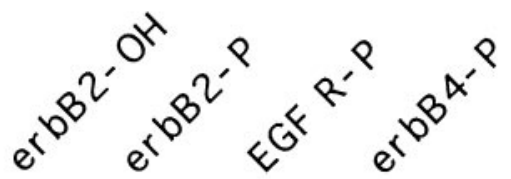
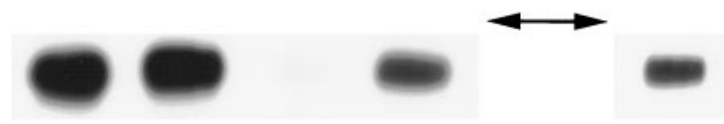


\section{APHID antibody \\ control nerve \\ cut distal stump}

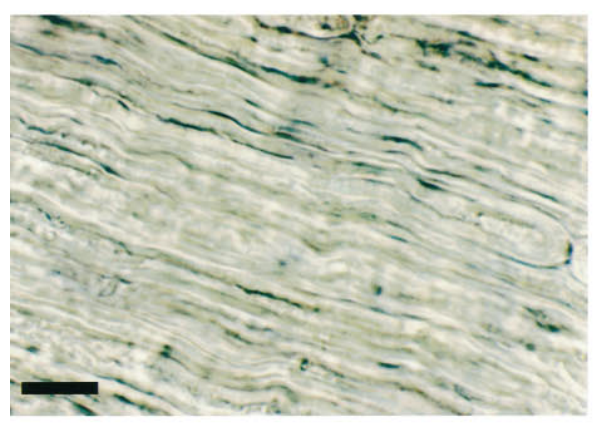

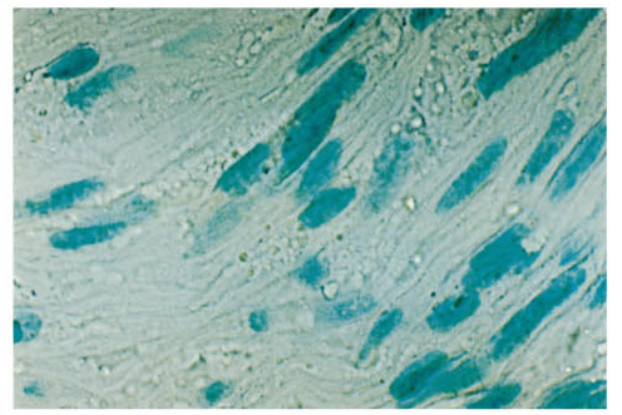

\section{APHID antibody: cut distal stump}
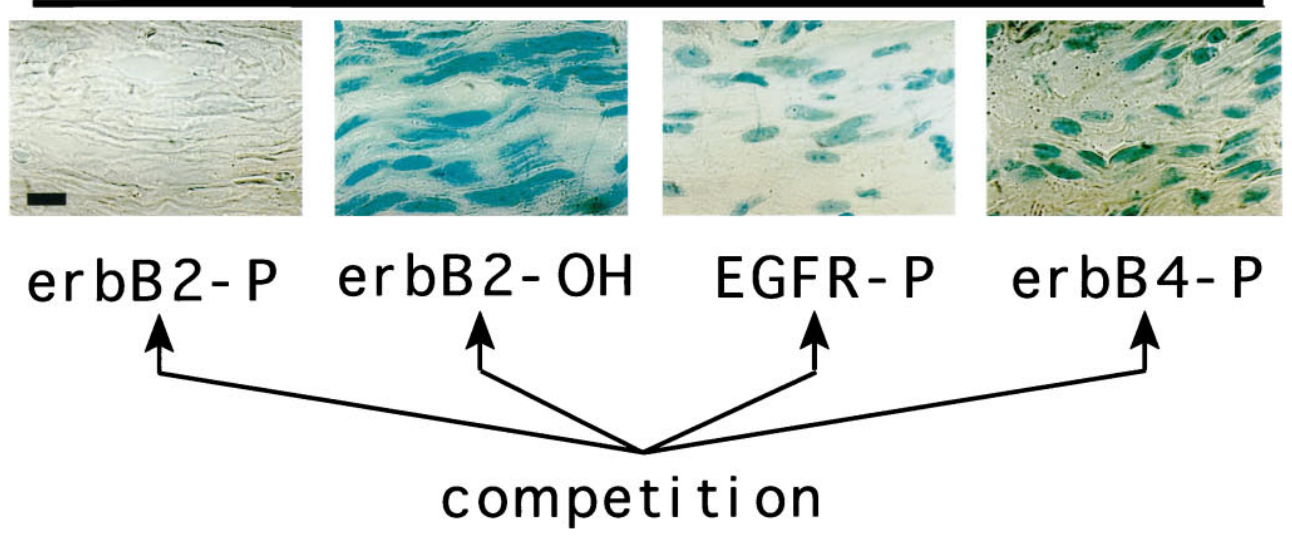

Figure 4. Phosphorylation of $\mathrm{p} 185^{\mathrm{erbB} 2}$ at Y1248 visualized in sciatic nerve Schwann cells during Wallerian degeneration. Top panels, Cryostat sections of control and distal stump of rat sciatic nerve at 2 weeks into Wallerian degeneration were immunostained with the APHID antibody to $\mathrm{p} 185^{\mathrm{erbB} 2}$ as described in Materials and Methods. Visualization with True Blue results in blue-green color over areas of immunoreactivity. Bottom panels, Controls for specificity of APHID antibody immunohistochemical stain. Sections of the distal stump of rat sciatic nerve at 2 weeks into Wallerian degeneration were stained with APHID antibody preincubated with peptides or phosphopeptides corresponding to NPXY motifs in p185 ${ }^{\mathrm{erbB} 2}$, EGF receptor, or $\mathrm{p} 180^{\mathrm{erbB} 4}$ as described in Materials and Methods. Scale bars, $15 \mu \mathrm{M}$.

\section{APHID erbB2}

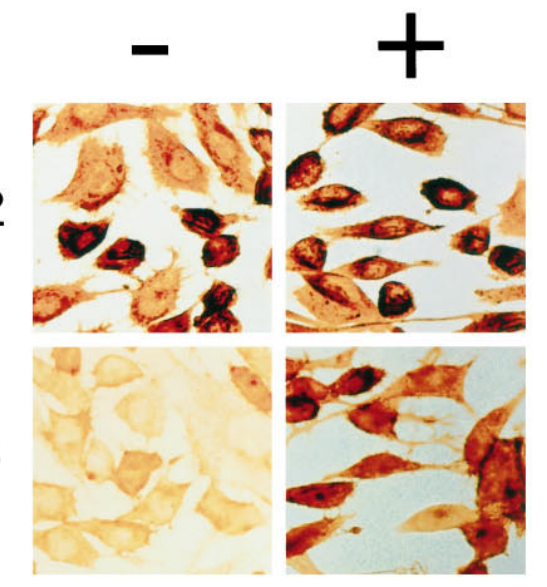

Figure 5. APHID antibody immunostaining is specific for activated receptors in cells expressing p185 ${ }^{\mathrm{erbB} 2}$. G8/DHFR cells were treated with phorbol or solvent control to generate inactive $(-)$ or activated $(+)$ p185 ${ }^{\text {erbB2 }}$ as described in Materials and Methods. The cells were immunostained with a commercial antibody that recognizes $\mathrm{p} 185^{\mathrm{erbB} 2}$ irrespective of activation state (top panels) or with the APHID antibody to activated p185 ${ }^{\mathrm{erbB} 2}$ (bottom panels) and visualized with DAB. For scale reference, G8/DHFR cell nuclei are $\sim 10 \mu \mathrm{M}$ in diameter. were then incubated overnight at $4^{\circ} \mathrm{C}$ with an S100- $\beta$ monoclonal antibody (Sigma, St. Louis, MO) followed by $\mathrm{Cy} 2$-conjugated goat antimouse IgG (Jackson Immunochemicals).

Bromodeoxyuridine labeling. For mitotic labeling, animals were injected with bromodeoxyuridine (BrdU; $50 \mathrm{mg} / \mathrm{kg}$, i.p.). After $1 \mathrm{hr}$, the animals were killed by intracardiac perfusion with $4 \%$ paraformaldehyde in PBS. Cryostat sections $(7.5 \mu \mathrm{m})$ of the nerves were prepared and stained with a monoclonal anti-BrdU primary antibody and fluorescein-conjugated secondary antibody according to the manufacturer's specifications (Boehringer Mannheim, Indianapolis, IN). Labeled nuclei were counted in five highpowered fields per nerve segment (two animals per time point) viewed by fluorescence optics (Leitz, Wetzlar, Germany; $40 \times$ objective). 


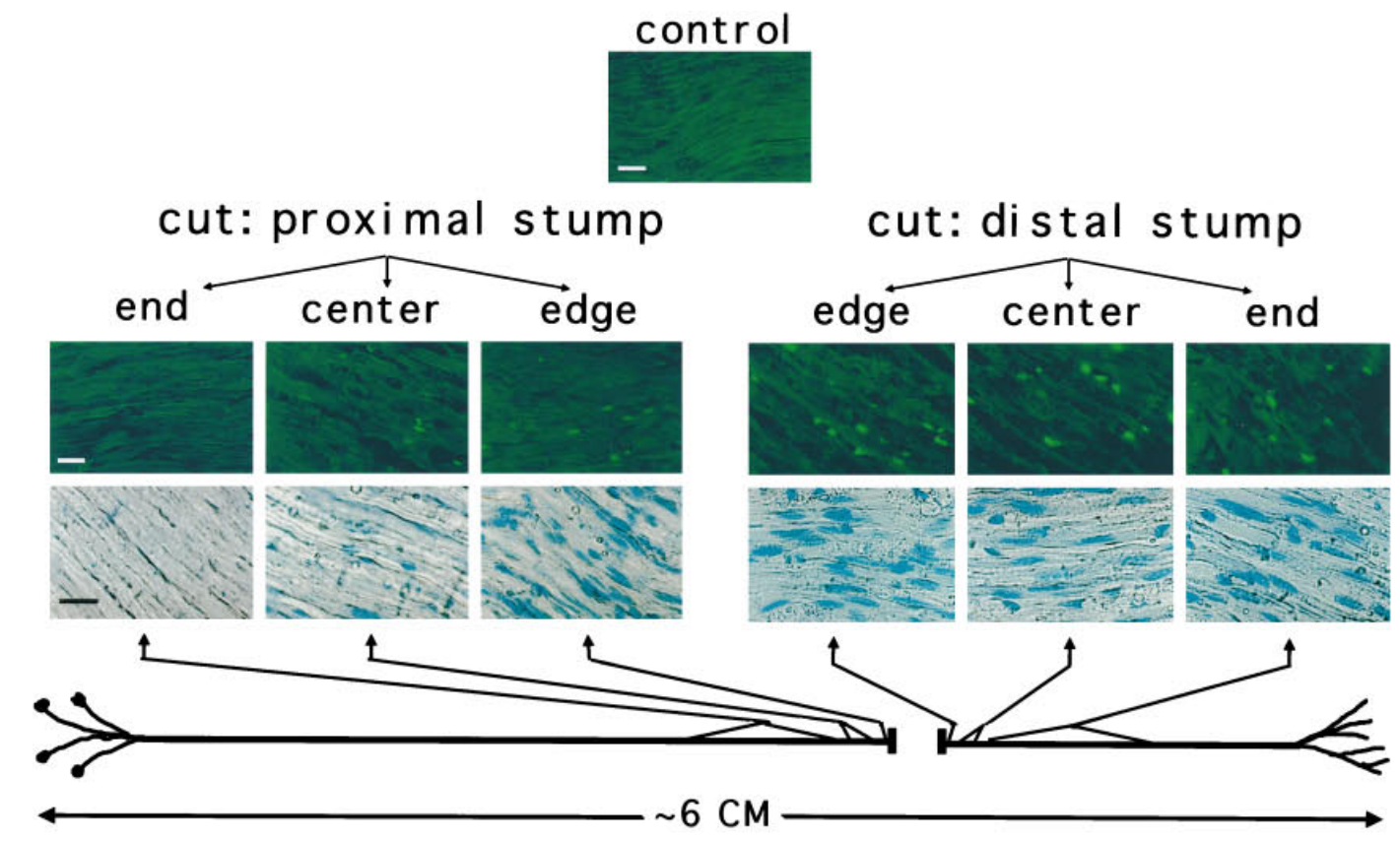

S100

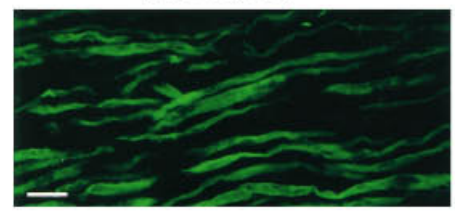

BrdU

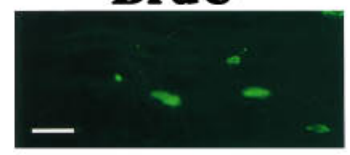

APHID

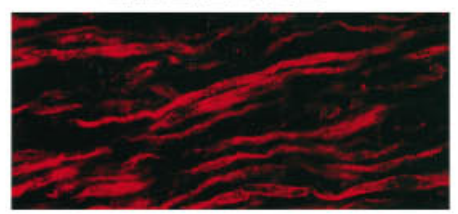

APHID

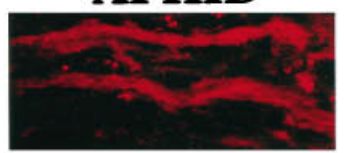

S100/APHID

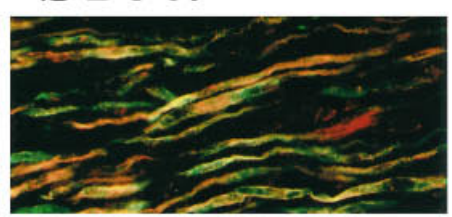

BrdU/APHID

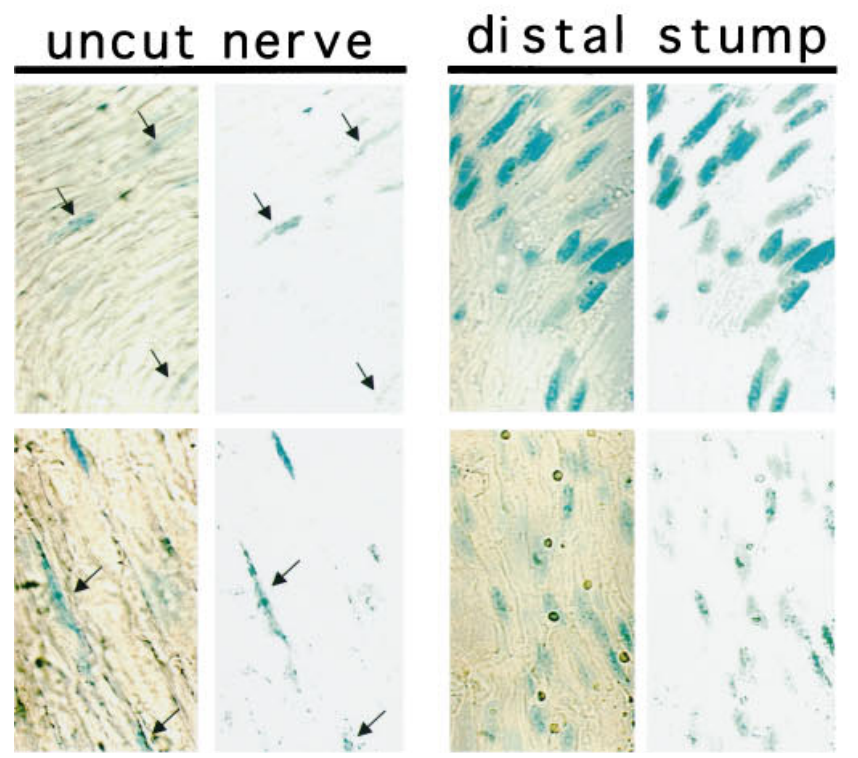

Figure 6. Top. Tight positional relationship between $\mathrm{p} 185^{\mathrm{erbB} 2}$ activation and BrdU labeling during Wallerian degeneration in sciatic nerve. Sections of proximal and distal stumps of rat sciatic nerve at 2 weeks into Wallerian degeneration were stained for BrdU uptake (top row) or with the APHID antibody (bottom row). Schematic diagram of sciatic nerve (cell bodies to left, nerve termini to right) illustrates approximate position of the nerve transection together with relative positions of the edge, center, and end segments. A control, uncut nerve section (top) stained for BrdU uptake is shown for comparison. Scale bars, $15 \mu \mathrm{M}$. 


\section{RESULTS}

\section{Schwann cell proliferation is temporally associated with activation of $\mathrm{p} 185^{\mathrm{erbB2}}$}

As an initial probe into the activation state of $\mathrm{p} 185^{\mathrm{erbB} 2}$ during Wallerian degeneration, we surgically transected rat sciatic nerve and ligated both the proximal and distal stumps. We monitored tyrosine phosphorylation of $\mathrm{p} 185^{\mathrm{erbB} 2}$ within the nerve segments 5-28 d after nerve transection, the period of Wallerian degeneration (Bradley and Asbury, 1970; Clemence et al., 1989). Sciatic nerve extracts were immunoprecipitated with a pan-p185 ${ }^{\text {erbB2 }}$ antibody, and the immunoprecipitates were immunoblotted with antiphosphotyrosine. Relative to control nerve sections, increased p185 ${ }^{\text {erbB2 }}$ tyrosine phosphorylation was found in the distal nerve stump between 5 and $18 \mathrm{~d}$ after transection (Fig. 1). To explore the temporal relationship between $\mathrm{p} 185^{\mathrm{erbB} 2}$ tyrosine phosphorylation and Schwann cell mitotic activity we monitored BrdU uptake over the same time frame. The BrdU uptake results (Fig. 2) show, as noted by others (Cohen et al., 1992), that mitotic activity is enhanced within 1 week after surgical transection of the nerve. Mitotic activity remains above baseline levels for at least $14 \mathrm{~d}$ but returns to control level by $28 \mathrm{~d}$ after injury. Thus p185 ${ }^{\text {erbB2 }}$ tyrosine phosphorylation and Schwann cell mitotic activity occur over the same broad time frame after nerve injury. To explore positional relationships between $\mathrm{p} 185^{\mathrm{erbB} 2}$ tyrosine phosphorylation and Schwann cell mitotic activity, we turned to an activation state-specific antibody targeted to $\mathrm{p} 185^{\mathrm{erbB} 2}$.

\section{Receptor specificity and activation state specificity of an APHID antibody to p185 erbB2}

In previous studies, we raised an APHID antibody directed to Y1248 in human p185 ${ }^{\mathrm{erbB} 2}$ (Epstein et al., 1992). This tyrosine lies within an NPXY motif which is a canonical target for the Shc adapter protein (Campbell et al., 1994; Dilworth et al., 1994; Stephens et al., 1994). Amino acid substitution experiments indicate that Y1248 is necessary for transforming activity of activated p185 ${ }^{\text {erbB2 }}$ (Segatto et al., 1990; Akiyama et al., 1991; Mikami et al., 1992). Moreover, reconstitution experiments indicate that phosphorylation of Y1248 couples $\mathrm{p} 185^{\text {erbB2 }}$ to the Ras-RafMAP kinase signal transduction pathway and is sufficient for transforming activity (Ben-Levy et al., 1994).

The erbB2 gene is a member of the subgroup I receptor tyrosine kinase family (Ullrich and Schlessinger, 1990) that includes the EGF receptor, p185 ${ }^{\mathrm{erbB} 2}$ (Peles et al., 1992), erbB3 (Kraus et al., 1989), and erbB4 (Plowman et al., 1993). To document receptor specificity and activation state specificity of the APHID antibody targeted to Y1248, we used an indicator cell line, G8/DHFR. This is a murine fibroblast line that overex- presses the rat $c$-erbB2 gene product. Semiconfluent G8/DHFR cells express an intermediate level of $c$-erbB2 receptor tyrosine kinase activity. This intermediate level of activity is suppressed by exposure to phorbol-based tumor promoters, which transmodulate the receptor (Epstein et al., 1990). As shown by immunoblot analysis of G8/DHFR cells (Fig. 3), our APHID antibody recognizes $\mathrm{p} 185^{\mathrm{erbB} 2}$ only in the activated state, whereas a conventional antibody reacts with the protein in the activated or inactivated state. Peptide competition experiments (Fig. 3) document receptor selectivity of the APHID antibody directed to Y1248 in $185^{\text {erbB2 }}$. The synthetic tyrosine phosphopeptide used to raise the antibody competes for recognition of activated p185 ${ }^{\mathrm{erbB} 2}$. An identical peptide without a phosphate at Y1248 does not compete. Phosphopeptides corresponding to positionally equivalent NPXY motifs in the C-terminal domain, the EGF receptor, and p180 erbB4 do not compete with the APHID antibody for recognition of activated $\mathrm{p} 185^{\mathrm{erbB} 2}$. The C-terminal portion of $\mathrm{p} 180^{\mathrm{erbB} 3}$ has no positional equivalent of the $\mathrm{p} 185^{\mathrm{erbB} 2}$ NPXY motif and was therefore not tested.

\section{Phosphorylation of $\mathrm{p} 185^{\mathrm{erbB} 2}$ at $\mathrm{Y} 1248$ visualized in sciatic nerve Schwann cells}

To determine whether the APHID antibody can be used as an immunocytochemical reagent to visualize $\mathrm{p} 185^{\mathrm{erbB} 2}$ signaling in vivo, we stained cryostat sections from control nerve and from the distal stump of sciatic nerve at 2 weeks into Wallerian degeneration, a time when receptor activation is at its zenith, as shown by immunoblot analysis with conventional reagents (Fig. 1). As shown in Figure 4, top panel, sections from transected sciatic nerve show much more immunoreactivity with the APHID antibody than control nerve sections. Selectivity of the APHID antibody as an immunocytochemical reagent is established by competition with the subgroup I receptor peptides and phosphopeptides. As shown in Figure 4, bottom panel, histochemical staining was completely ablated by competitions with the erbB2 phosphopeptide. Competitions with erbB2 peptide or other subgroup I receptor phosphopeptides had little or no effect on staining. Double labeling with an antibody to S100 protein confirms that cells that react with APHID antibody are Schwann cells (see Fig. 7). In both proximal and distal stump sections, the APHID antibody immunostaining is localized diffusely over the surface of reactive cells, as predicted for a cell surface protein in $7.5 \mu \mathrm{m}$ cryostat sections. We obtained a similar pattern of immunostaining using a different APHID antibody directed to tyrosines 1221 and 1222 that also are autophosphorylated in activated $\mathrm{p} 185^{\mathrm{erbB} 2}$ (data not shown). As a positive control for immunohistochemistry in sciatic nerve sections, we used the

\section{$\leftarrow$}

Figure 7. Middle. Colocalization of activated $\mathrm{p} 185^{\mathrm{erbB} 2}$, Schwann cell marker protein, and BrdU incorporation by double immunofluorescence. Top panels, Sections of distal stumps of rat sciatic nerve at 2 weeks into Wallerian degeneration were costained with a monoclonal antibody to S100 protein and the APHID antibody to p185 ${ }^{\text {erbB2}}$ followed by secondary antibodies conjugated to Cy2 (S100) or Cy3 (p185 ${ }^{\text {erbB2}}$ ). Colocalization of S100 ( green) and activated $185^{\mathrm{erbB} 2}$ (red) is indicated in the color overlay (yellow). Bottom panels, Sections were immunostained with the APHID antibody to $\mathrm{p} 185^{\mathrm{erbB} 2}$ and visualized with $\mathrm{Cy} 3$. BrdU uptake was visualized in the same sections with an antibody to BrdU followed by a Cy2-conjugated secondary antibody. Colocalization of BrdU uptake (green) and activated $\mathrm{p} 185^{\mathrm{erbB} 2}$ (red) is indicated in the color overlay. The somewhat inferior quality of activated $185^{\text {erbB2 }}$ immunostaining reflects the fact that the sections must be exposed to partially denaturing conditions for BrdU immunostaining before staining for activated $\mathrm{p} 185^{\mathrm{erbB} 2}$.

Figure 8. Bottom. Nerve damage increases the amount of activated p185erbB2 per cell. Cryostat sections of uncut sciatic nerve or transected nerve (distal stump) at 2 weeks into Wallerian degeneration were stained with the APHID antibody to $185^{\text {erbB } 2}$ (top row) or a conventional antibody to $\mathrm{p} 185^{\text {erbB2 }}$ (pAb-1, bottom row). To aid in visualization of stained cells, photomicrographs were taken at identical exposure settings, scanned, and digitized into the Adobe Photoshop program. Background color was deleted electronically. Weakly stained cells in the processed images from uncut nerve and distal stump (arrows) can be matched to positional equivalents in the unprocessed photomicrographs. 
G8/DHFR cell line. As shown in Figure 5, the APHID antibody recognizes $\mathrm{p} 185^{\mathrm{erbB} 2}$ on G8/DHFR cells only when $\mathrm{p} 185^{\mathrm{erbB} 2}$ is active. By contrast, a conventional antibody to $\mathrm{p} 185^{\mathrm{erbB} 2}$ (pAb-1) recognizes $\mathrm{p} 185^{\mathrm{erbB} 2}$ irrespective of its activation state. Collectively, these data indicate that the staining differential between control and transected nerve sections shown in Figure 4, top panel, most likely reflects the activation of $\mathrm{p} 185^{\mathrm{erbB} 2}$ in Schwann cells.

\section{Tight linkage between $\mathrm{p} 185^{\text {erbB2 }}$ activation and BrdU labeling during Wallerian degeneration in sciatic nerve}

Using the APHID antibody as an immunohistochemical reagent, we established a tight positional relationship between Schwann cell mitotic activity and $\mathrm{p} 185^{\mathrm{erbB} 2}$ signaling functions during Wallerian degeneration (Fig. 6). In the distal stump of transected nerve, cells that stain with the APHID antibody are distributed uniformly from the edge of the lesion to the end of the nerve segment. Double-labeling experiments indicate that BrdU incorporation occurs predominantly within Schwann cells (Fig. 7). Thus, the distribution of APHID antibody immunostained cells tracks well with Schwann cell mitotic activity, as visualized by BrdU labeling. The proximal stump of the nerves reveals a different immunostaining pattern for both APHID antibody and BrdU label but with the same tight positional coincidence. Here, APHID antibody staining and mitotic activity are seen at the edge of the nerve lesion. However, beyond the edge of the lesion proximal toward the nerve cell bodies, APHID antibody staining and mitotic activity are attenuated to the level seen in uncut nerve.

\section{Enhanced Schwann cell staining with APHID antibody reflects activation state, rather than abundance, of $p 185^{\text {erbB2 }}$}

Both erbB2 mRNA and p185 ${ }^{\text {erbB2}}$ accumulate in the distal stump of sciatic nerve during Wallerian degeneration (Cohen et al., 1992; Carroll et al., 1997). The number of Schwann cells in the distal stump also increases as a consequence of mitotic activity. Accordingly, we wondered whether the increased staining with APHID antibody reflects a gain in the number of cells that display activated $\mathrm{p} 185^{\mathrm{erbB} 2}$ or an increase in the amount of activated $\mathrm{p} 185^{\mathrm{erbB} 2}$ per cell or both. To address this question, we compared immunostaining patterns with our APHID antibody with those obtained with a commercial antibody that recognizes $\mathrm{p} 185^{\mathrm{erbB} 2}$ irrespective of activation state. To visualize the staining differential more readily, we used image-processing software to subtract background color in the stained sections.

Relative to uncut nerve, distal stump sections stained with APHID antibody show a gain in both number of stained cells and staining intensity per cell (Fig. 8, top row). By contrast (Fig. 8, bottom row), identical sections stained with conventional antibody show a gain in the number of stained cells (in confirmation of Cohen et al., 1992), but the staining intensity per cell is comparable in uncut nerve and distal stump. This comparison is somewhat subjective, because immunohistochemical staining reactions are not inherently linear. However, the differential intensity of cell staining with the APHID antibody was apparent to the eye in multiple experiments.

\section{DISCUSSION}

Targeted disruption studies show that the neuregulin and erbB2 gene products play vital roles in development of the embryonic heart, Schwann cell precursors, and cranial nerve ganglia (Gassman et al., 1995; Lee et al., 1995; Marchionni, 1995; Meyer and Birch- meier, 1995). However, because null mutants of either gene die in utero at day 10.5, the functions of neuregulins and their receptors in adult animals cannot be discerned by gene disruption. The APHID antibody images shown here indicate that these proteins play an active role in the regeneration of injured nerves in adult animals.

Activation of $\mathrm{p} 185^{\mathrm{erbB} 2}$ after nerve damage could, in principle, reflect suppression of a negative regulator. In tissue culture model systems, the activity state of $\mathrm{p} 185^{\mathrm{erbB} 2}$ is negatively regulated by protein kinase C agonists (Dougall et al., 1994). For several reasons, however, we favor the view that activation of $\mathrm{p} 185^{\mathrm{erbB} 2}$ reflects increased availability of $\mathrm{p} 185^{\mathrm{erbB} 2}$-activating ligands, the neuregulins. Neuregulins are produced by neurons (Marchionni et al., 1993; Dong et al., 1995) in a variety of splice variant transcripts, some of which encode a membrane-bound ligand (Marchionni et al., 1993). Immunohistochemical studies demonstrate neuregulins within axons (Sandrock et al., 1995), and neuronal membrane preparations stimulate the growth of cultured Schwann cells (Salzer et al., 1980) through the activation of p185 ${ }^{\text {erbB2 }}$ (Morrissey et al., 1995).

Neuregulins are thought to interact with $\mathrm{p} 185^{\mathrm{erbB} 2}$ by inducing the formation of heterodimers between $\mathrm{p} 185^{\mathrm{erbB} 2}$ and either p180 ${ }^{\text {erbB3 }}$ or $\mathrm{p} 180^{\text {erbB4}}$. Neuregulin-induced heterodimer formation between $\mathrm{p} 185^{\mathrm{erbB} 2}$ and $\mathrm{p} 180^{\mathrm{erbB} 3}$ constitutes an interesting example of a symbiotic relationship in receptor signaling. By itself, $\mathrm{p} 185^{\text {erbB2 }}$ cannot interact with neuregulins. Although $\mathrm{p} 180^{\mathrm{erbB} 3}$ is a competent neuregulin-binding protein, it appears to have no intrinsic tyrosine kinase activity (Carraway and Cantley, 1994). Formation of a heterodimeric p185 ${ }^{\text {erbB2}}-\mathrm{p} 180^{\text {erbB3 }}$ complex generates a fully competent growth factor receptor (Carraway and Cantley, 1994; Marchionni, 1995; Wallasch et al., 1995). In preliminary studies, we have noted that $\mathrm{p} 180^{\mathrm{erbB} 3}$ is present in rat sciatic nerve lysates (data not shown) (Carroll et al., 1997).

The anatomy of sciatic nerve raises an interesting question. If neuregulin synthesis is confined to neurons, what serves as a source of neuregulin for Schwann cells in the distal stump of a regenerating nerve? Neuronal protein synthesis is mainly confined to the nerve cell bodies. Accordingly, only neuregulins synthesized before transecting the nerve would have access to Schwann cells in the distal stump. Fischbach and associates have described a slow release mechanism for neuregulins at the sciatic nerve ending. Here within the neuromuscular junction, neuregulin is bound to extracellular matrix and inhibited from activating $\mathrm{p} 185^{\mathrm{erbB} 2}$ on striated muscle until it is released by proteolysis (Goodearl et al., 1995; Loeb and Fischbach, 1995; Sandrock et al., 1995). Conceivably, stored reservoirs of inactive neuregulin are distributed along the length of the axon to be activated and slowly released as axons degenerate after transection of the nerve. Alternatively, neuregulins may be synthesized by non-neuronal cells during Wallerian degeneration, perhaps by Schwann cells themselves in an autocrine growth mode (Carroll et al., 1997). Finally, the phosphorylation of $\mathrm{p} 185^{\mathrm{erbB} 2}$ may be triggered by a novel and presently uncharacterized ligand that is released after nerve damage.

Future studies with APHID antibodies targeted to other members of the subgroup I receptor family may identify heterodimeric partners and the source of ligand for $\mathrm{p} 185^{\mathrm{erbB} 2}$ during nerve regeneration. In the meantime, it is worth noting that the approach taken here to provide images of $\mathrm{p} 185^{\mathrm{erbB} 2}$ activation in vivo has general utility. Synthetic phosphopeptides can, in principle, be used to raise APHID antibodies targeted to any growth factor receptor or signal-generating protein that is regulated by 
tyrosine phosphorylation events. As immunochemical probes, these APHID antibodies are more selective than conventional reagents, and they can be used as immunohistochemical reagents to display the activation state of specific receptors or signal generators in situ.

\section{REFERENCES}

Akiyama T, Matsuda S, Namba Y, Saito T, Toyoshima K, Yamaoto T (1991) The transforming potential of the c-erbB-2 protein is regulated by its autophosphorylation at the carboxyl-terminal domain. Mol Cell Biol 11:833-842.

Bangalore L, Tanner AJ, Laudano AP, Stern DF (1992) Antiserum raised against a synthetic phosphotyrosine-containing peptide selectively recognizes $185^{\text {neu/erbB-2 }}$ and the epidermal growth factor receptor. Proc Natl Acad Sci USA 89:11637-11641.

Ben-Levy RB, Paterson HF, Marshall CJ, Yarden Y (1994) A single autophosphorylation site confers oncogenicity to the Neu/ErbB-2 receptor and enables coupling to the MAP kinase pathway. EMBO J 13:3302-3311.

Bradley WG, Asbury AK (1970) Duration of synthesis phase in neurilemma cells in mouse sciatic nerve during regeneration. Exp Neurol 26:275-282.

Campbell KS, Ogris O, Burke B, Su W, Auger KR, Druker BJ, Schaffhausen BS, Roberts TM, Pallas DC (1994) Polyoma middle tumor antigen interacts with SHC protein via the NPTY (Asn-Pro-Thr-Tyr) motif in middle tumor antigen. Proc Natl Acad Sci USA 91:6344-6348.

Carraway KI, Cantley L (1994) A neu acquaintance for ErbB3 and ErbB4: a role for receptor heterodimerization in growth signaling. Cell 78:5-8.

Carroll SL, Miller ML, Frohnert PW, Kim SS, Corbett JA (1997) Expression of neuregulins and their putative receptors, erbB2 and erbB3, is induced during Wallerian degeneration. J Neurosci 17:1642-1659.

Clemence A, Mirsky R, Jessen KR (1989) Non-myelin-forming Schwann cells proliferate rapidly during Wallerian degeneration in the rat sciatic nerve. J Neurocytol 18:185-192.

Cohen J, Yachnis A, Arai M, Davis J, Scherer S (1992) Expression of the neu proto-oncogene by Schwann cells during peripheral nerve development and Wallerian degeneration. J Neurosci Res 31:622-634.

Dilworth SM, Brewster CEP, Jonew MD, Lanfrancone L, Pelicci G, Pelicci PG (1994) Transformation by polyoma virus middle T-antigen involves the binding and tyrosine phosphorylation of Shc. Nature 367:87-90.

Dong Z, Brennan A, Liu N, Yarden Y, Lefkowitz G, Mirsky R, Jessen K (1995) Neu differentiation factor is a neuron-glia signal and regulates survival, proliferation and maturation of rat Schwann cell precursors. Neuron 15:585-596.

Dougall W, Qian X, Peterson N, Miller M, Samanta A, Greene M (1994) The neu-oncogene: signal transduction pathways, transformation mechanisms and evolving therapies. Oncogene 9:2109-2132.

Epstein RJ, Druker BJ, Roberts TM, Stiles CD (1990) Modulation of a Mr 175,000 c-neu receptor isoform in G8/DHFR cells by serum starvation. J Biol Chem 265:10746-10751.

Epstein R, Druker B, Roberts T, Stiles CD (1992) Synthetic phosphopeptide immunogens yield activation-specific antibodies to the $\mathrm{c}$ erbB-2 receptor. Proc Natl Acad Sci USA 89:10435-10439.

Fawcett JW, Keynes RJ (1990) Peripheral nerve regeneration. Annu Rev Neurosci 13:43-60.

Gassman M, Casagranda F, Orioli D, Simon H, Lai C, Klein R, Lemke G (1995) Aberrant neural and cardiac development in mice lacking the erbB4 neuregulin receptor. Nature 378:390-394.

Goodearl A, Yee A, Sandrock AJ, Corfas G, Fischbach G (1995) ARIA is concentrated in the synaptic basal lamina of the developing chick neuromuscular junction. J Cell Biol 130:1423-1434.
Harlow E, Lane D (1988) Antibodies: a laboratory manual. Cold Spring Harbor, NY: Cold Spring Harbor Laboratory.

Jin J, Nikitin A, Rajewsky M (1993) Schwann cell lineage-specific neu(erbB-2) gene expression in the developing rat nervous system. Cell Growth Differ 4:227-237.

Kraus M, Issing W, Miki T, Popescu N, Aaronson S (1989) Isolation and characterization of erbB3, a third member of the erbB/epidermal growth factor receptor family: evidence for overexpression in a subset of human mammary tumors. Proc Natl Acad Sci USA 86:9193-9197.

Lee K-F, Simon H, Chen H, Bates B, Hung M-C, Hauser C (1995) Requirement for neuregulin receptor erbB2 in neural and cardiac development. Nature 378:394-398.

Loeb J, Fischbach G (1995) ARIA can be released from extracellular matrix through cleavage of a heparin-binding domain. J Cell Biol 130:127-135.

Marchionni M (1995) Neu tack on neuregulin. Nature 378:334-335.

Marchionni M, Goodearl A, Chen M, McDonogh O, Kirk C, Hendricks M, Danehy F, Misumi D, Sudhalter J, Kobayashi K, Wroblewki D, Lynch C, Baldassare M, Hiles I, Davis J, Hsuan J, Totty N, Otsu M, McBurney R, Waterfield M, Stroobant P, Gwynne D (1993) Glial growth factors are alternatively spliced erbB2 ligands expressed in the nervous system. Nature 362:312-318.

Meyer D, Birchmeier C (1995) Multiple essential functions of neuregulin in development. Nature 378:386-389.

Mikami Y, Davis JG, Dobashi K, Dougall WC, Myers JN, Brown V, Greene MI (1992) Carboxyl-terminal deletion and point mutations decrease the transforming potential of the activated rat neu oncogene product. Proc Natl Acad Sci USA 89:7335-7339.

Morrissey T, Levi A, Nuijens A, Sliwkowski M, Bunge R (1995) Axoninduced mitogenesis of human Schwann cells involves heregulin and p185erbB2. Proc Natl Acad Sci USA 92:1431-1435.

Peles E, Bacus EE, Koski RA, Lu HS, Wen D, Ogden SG, Levy RB, Yarden Y (1992) Isolation of the Neu/HER-2 stimulatory ligand: a 44 $\mathrm{kDa}$ glycoprotein that induces differentiation of mammary tumor cells. Cell 69:205-216.

Plowman G, Culouscou J-M, Whitney G, Green J, Carlton G, Foy L, Newbauer M, Shoyab M (1993) Ligand-specific activation of HER4/ p180erbB4, a fourth member of the epidermal growth factor receptor family. Proc Natl Acad Sci USA 90:1746-1750.

Salzer J, Williams A, Glaser L, Bunge R (1980) Studies of Schwann cell proliferation. II. Characterization of the stimulation and specificity of the response to a neurite fraction. J Cell Biol 84:753-766.

Sandrock AJ, Goodearl A, Yin Q-W, Chang D, Fischbach G (1995) ARIA is concentrated in nerve terminals at neuromuscular junctions and at other synapses. J Neurosci 15:6124-6136.

Segatto O, Lonardo F, Pierce JH, Bottaro DP, DiFiore PP (1990) The role of autophosphorylation in modulation of erbB-2 transforming function. New Biol 2:187-195.

Stephens RM, Loeb DM, Copeland TD, Pawson T, Greene LA, Kaplan DR (1994) Trk receptors use redundant signal transduction pathways involving SHC and PLC- $\gamma 1$ to mediate NGF responses. Neuron 12:691-715.

Ullrich A, Schlessinger J (1990) Signal transduction by receptors with tyrosine kinase activity. Cell 61:203-212.

Wallasch C, Weiss FU, Niederfellner G, Jallal B, Issing W, Ullrich A (1995) Heregulin-dependent regulation of HER2/neu oncogenic signaling by heterodimerization with HER3. EMBO J 14:4267-4275.

Waller A (1851) Experiments on the section of the glosso-pharyngeal and hypoglossal nerves of the frog, and observations of the alterations produced thereby in the structures of their primitive fibers. Edinburgh Med Surg J 76:369-376. 